\title{
Thoroughly Applying Scientific Outlook on Development Implementing Sustainable Development Strategy in Higher Vocational Colleges
}

\author{
Zhi Li \\ Hubei Urban Construction Vocational and Technology College \\ Wuhan, Hubei Province, 430205, China \\ E-mail: hubeiwyh@163.com \\ Youhua Wang \\ Hubei Urban Construction Vocational and Technology College \\ Wuhan, Hubei Province, 430205, China
}

Fund project: Cultural Construction and Management in Higher Vocational Colleges, the subject of China Education Institute (project no. 0401265A), the director of the subject is Zhi Li.

\begin{abstract}
To make breakthroughs, obtain further development, and win in the fierce competition, higher vocational colleges must apply scientific outlook on development, set up students-and-teachers oriented educational concept, enhance connotation construction, create competition advantages so as to fully improve education and teaching quality and realize sustainability development.
\end{abstract}

Keywords: Scientific outlook on development, People-oriented, Connotation construction, Sustainable development

Scientific outlook on development is the significant strategy ideology for the development of socialism with Chinese characteristics, is the important guidelines for the development of China's economy society, and is also the important guiding ideology for the development of higher vocational education. In the construction, reforms and development of higher vocational colleges, scientific outlook on development shall be applied thoroughly so as to realize sustainable development of vocational colleges.

\section{To set up students-and-teachers oriented educational concept}

It is raised in the Report to the Seventeenth National Congress of the Communist Party of China that "Endeavor to build education that people are satisfied with" is the material incarnation of people oriented ideology of scientific outlook on development on education aims. To apply thoroughly scientific outlook on development and to be people oriented, in terms of higher vocational college educational concepts, means to set up students-and-teachers oriented education concept.

\subsection{To set up student oriented education concept and to serve the growth of students}

The development of higher vocational colleges aims at cultivating highly skilled talents for the society who have comprehensive development in morality, intelligence, fitness and virtue. In the process of applying scientific outlook on development, to build the morality and to teach to be good people shall be considered the fundamental task so as to serve the growth of students.

\subsubsection{To build morality and to teach to be good people}

Higher vocational colleges shall stick to the concept where to teach to be a good person is the root and morality education shall enjoy priority, and shall take building morality and teaching to be good people as the fundamental task. Higher vocational colleges shall implement makings education to all students and through the involvement of all students and the monitoring in the entire process, colleges should realize comprehensive education, including teaching education, service education, management education and environment education, through which students will be 
educated to be the constructors and successors for socialism construction. Hubei Urban Construction Vocational and Technology College (hereinafter referred to as "HUCVTC") attaches great importance to morality education and takes "building morality, admiring ability, earnest learning, and innovation" as our guide, which is considered as the important part in enhancing education reforms and improving talents' makings. HUCVTC also takes scientific outlook on talents, quality and teaching as the guidelines, integrates ideological and political education into the whole talent-cultivating process, and forms a morality education pattern where "ideological and political course" is the leading part, specialty courses is the support, and extracurricular science and technology, literary and sports activities and social practices are the supplements.

\subsubsection{To cultivate students of harmonious development}

We shall stick to people oriented concept and enhance comprehensive development of students, which is the basic requirement raised by scientific outlook on development on vocational education. In higher vocational education, professional skill cultivation and literature spirit shall be combined together organically. It is a must to emphasize professional makings cultivation. However, cultivation on students' literature spirit and comprehensive and harmonious development of students' literature spirit shall not be neglected. Therefore, HUCVTC enhances students' literature spirit cultivation and harmonious development of students through enhancing psychological health education and psychological makings training, adding elective courses on literature, science and technology, art and psychology and giving various lectures.

\subsubsection{Caring about and serving students}

To recognize and respect education objects is the premise for being a teacher or it will move educational teaching management base. For one hand, teachers shall contact students frequently, care about students, get to know students, and study the psychology of students so as to make teaching and learning harmonious. In daily management and teaching, it is hard to avoid that in students' study and life, there will be insufficient preparations. It may be students' problems or schools' problems. Hence, we need to provide channels for students to make complaints and to put forward opinions. Through multi-style and multi-level symposiums, we could collect students' opinions and handle students' complaints and problems properly. Further, through correct guiding, we need to help students to correctly recognize the relationship between ideality and reality. For another hand, students' employment should be placed at the prominent position. It is raised in the report to the Seventeenth National Congress of the Communist Party of China that "obtaining employment is the people's livelihood". The fundamental road for higher vocational colleges to solve students' employment is to scientifically set up specialties and timely adjust specialties according to social requirements. What is more, colleges could set up employment base through college-enterprise cooperation system so as to resolve students' employment.

\subsection{To set up teacher oriented teaching concept and to rely on teachers for good education}

Education is a major program of lasting importance, in which teachers are one of the basic elements and are the main body for colleges' teaching mode and teaching mode innovation. A team of teachers of high makings is the key in cultivating talents of high makings and is the root of core competition force of a college. The reason why many higher vocational colleges could form their teaching features and realize comprehensive, harmonious and sustainable development is that they own a group of excellent teaching and scientific research talents, management talents and specialty leading teachers of high levels.

HUCVTC ensures the central position of teaching through making a series of policies and rules and actively creating atmosphere where teaching and teachers are given priority and teachers are highly respected. In professional skill duty evaluation and engagement, human policy system reform, distribution system reform and post subsidy, HUCVTC gives priority to teachers and encourages teachers and teaching management personnel to take part in academic activities off college and to attend advanced studies, for which HUCVTC provides guarantee both from time and funds. At the same time, HUCVTC endeavors to constantly improve teachers' income level and living quality. In reforms, humanism care is shown. HUCVTC fully activates positive elements from various aspects and conducts good higher vocational education by relying on teaching staff.

HUCVTC always views teaching team construction as the basic, crucial and strategy work in education career. Through enhancing internal and external training on teaching management personnel, endeavoring to conduct "double title teachers" team construction, implementing "tutorial system", and retaining professional technicians from enterprises or other organizations or skillful craftsmen to assume teaching task, HUCVTC is constructing a "double title teachers", part time and full time combined, and professional teaching team, whose structure is reasonable in the title of technical posts, education degree, double teachers and part time and full time teachers and whose teaching capacity, specialty capacity, practice capacity and vocational education research capacity are comprehensively developed.

\section{To enhance connotation construction and to realize sustainable development of higher vocational colleges}

Higher vocational education must take initiative to adapt to social demands and place the key point of reform and development on enhancing connotation construction, improving education quality, and providing highly skilled talents 
for socialism construction with Chinese characteristics. To make breakthroughs, make further develop and win in fierce competition, higher vocational colleges must take scientific outlook on development as the guideline, enhance connotation construction, and create competition advantages so as to fully improve education and teaching quality and realize sustainable development.

\subsection{Leadership capacity construction}

It is pointed out in the Report to the Seventeenth National Congress of the Communist Party of China that to improve leadership level and governance capacity shall be the core contents for leadership construction in various levels and shall be done in good mode. Strong capacity of leadership in vocational colleges is the key for promoting education and teaching reforms in vocational colleges and for constructing excellent vocational colleges. Besides strong enterprise and strong sense of duty, leadership of colleges shall also hold advanced teaching concepts and have good learning capacity, decision-making capacity, execution capacity, innovation capacity and personality charms. As leaders in higher vocational colleges, they should pay special attention to studying the guidelines and policies of our country on vocational education development, learning advanced vocational education concepts home and abroad, and correctly mastering objective situation of China's vocational education. In teaching practices, based on the policies of China, leaders should abstract teaching concepts by inheriting good traditions, making innovation, learning from other colleges, and presenting era spirit. Under the guiding of scientific outlook on development, leaders should make scientific decisions and push forward development of their colleges. In teaching practices, they should be good at finding out and resolving problems, be innovative, be brave to fight against difficulties, and dare to make exploration.

\subsection{Teaching concepts}

New development strategy needs new concepts to bolster them. Human beings could pass through wrong areas and march towards bright future because we are guided by new concepts. Higher vocational colleges have formed their teaching concepts in their development. After practices in certain period of time, errors could be found and colleges are confronted with difficulties, at which time we need to "diagnose" the concepts and make certain adjustment so as to make it more mature. HUCVTC, based on national policies and taking into consideration economic and social development of Hubei and the actual condition of HUCVTC, conducted wide discussion and researches and then fixed our teaching concept, that is "reinforcing college and enterprise cooperation and engineering combination; setting up specialties according to the needs of market, setting up courses according to posts, and enhancing skills based on employment requirements". Under the guide of this new teaching concept, HUCVTC effectively advanced connotation construction. In recent years, the development of HUCVTC is showing advantage.

\subsection{College orientation}

If to show special features, besides having special teaching concepts, higher vocational colleges shall also make scientific orientation from the following six perspectives, goals, types, levels, specialties, and teaching modes. Only when colleges make scientific orientation, could there be no fickle phenomenon and could teachers carefully follow teaching concept in their vocational education practices. The orientation of HUCVTC could be summarized as "basing on Hubei province, facing the entire nation, actively adapting to the demands of market on talents and the needs of social development, and serving regional economy construction; basing on architecture, facing construction system, taking higher vocational education of faculty level as the main body, and combining non-education-degree education, such as post training and national occupation certification; taking specialties of civil engineering as the lead and specialties of construction as the main body with the crossing penetration of specialties in management and information, and seeking for stable development; enhancing teaching mode where college establishes cooperation with enterprises and sets up engineering specialty combination in order to enable HUCVTC to become a provincial demonstrating higher vocational and technology college who is famous nation-wide in the field of construction and who takes the lead in national higher vocational colleges of similar type.

\subsection{Industry and college's cooperation in education}

The combination of industry, schools and researches is the necessary road for development of higher vocational education. To survive in the competition and to seek development, higher vocational colleges shall also integrate social resources outside colleges to speed up the construction of connotation. In recent years, HUCVTC has been integrating resources outside school through the board of directors of college and enterprises and has been cooperating with enterprises in the set-up of specialties, cultivation aims and specifications, and cultivation plan deigns, in the teaching of theories and practice courses, in making industrial, technological and post standards and education standards and giving technical trainings facing the society and industries, in helping enterprises resolve technology difficulties and promote projects, in mutually engaging employees, in students' internship and real trainings, in internal and external real training base construction, and in teachers' assuming or involvement in scientific researches of enterprises. The eight types of cooperation are united to realize industry and college's cooperation in education. 


\subsection{Teaching mode}

To achieve sustainable development, higher vocational colleges must enhance construction on specialty development and construction, course system and contents, practice teaching construction and talent cultivation modes. Especially, higher vocational colleges must form talent cultivation modes with distinguished features. HUCVTC once tried " $2+1$ " teaching mode only to find that it is too difficult in practice. In order to improve post competencies of students and decrease burdens on enterprises, HUCVTC, based on the characteristics of architecture specialties, applied " $2+0.5+0.5$ " teaching mode, a mode that combines engineering, so as to train occupational makings and competencies of students. In the process of promoting the combination of engineering, we developed new teaching mode which focuses on training the occupational skills of students, such as order, project orientation, real simulation trainings and task driving, and applied real simulation teaching methods, project teaching method, role playing method, on the scene teaching method, phase progressing method, case teaching method, and introducing enterprise rule and industrial certification.

\subsection{Specialty reforms and construction}

Higher vocational colleges shall track the changes of market needs timely, take initiative to adapt to the needs of regions, industrial economy and social development and adjust and set up specialties with pertinence. HUCVTC proactively adapts to regional economy and development needs of the society, adjusts and optimizes specialty structure at proper times, and forms 5 specialty groups with civil engineering specialties as the lead, with the construction specialties as the main body, and with the cross penetration of management and information specialties. HUCVTC strengthens course contents of architecture engineering technology specialties that focus on energy saving and ejection decreasing, gives prominence to reform on courses for architecture decoration technology specialties that focus on exterior and interior environment quality, and reinforces construction on courses for engineering cost specialties that focus on decreasing real estate construction costs.

\subsection{Course construction and reform}

Specialty course reform is the core of course reform. HUCVTC starts from meeting the demands of industry and local economy construction and constructs specialty course system on the basis of full analysis on occupation post competencies. Firstly, according to various occupational competency structure knowledge course modules, HUCVTC vigorously updates education ideology and concept. In the set-up of specialty course, HUCVTC introduces industrial technology standards and post standards, establishes specialty course set-up system that shows various "occupational competency standards", and forms practice teaching system that includes course training, special project training, and comprehensive training and post internship. Secondly, HUCVTC focuses on giving prominence to specialty features, strengthens specialty course teaching, and improves specialty competency of students. In order to give prominence to the specialty feature of students, HUCVTC resolves the situation where there are too many basic courses and course hour is too long while the course hours for specialty course are not sufficient, reinforces specialty skill training, cuts the too-difficult contents of the basic course, and increases the applicability of specialty course contents.

\subsection{Experiment real-training base construction}

To enhance real training and construction on practice base is the key part for higher vocational colleges to improve teaching condition, form teaching feature and increase teaching quality. For one hand, HUCVTC highly emphasizes construction on practice teaching conditions and constructs 153 independent and mutual-complement practice teaching bases inside and outside college. Under the guide of college and enterprise board of directors, HUCVTC constructs on-campus real-training base that unifies teaching, training, service and appraisal and that has "real simulation" function. This base takes engineering entity as the background, takes structure and construction craftwork exhibition models as the carrier, takes real simulated place as the scene and takes competency cultivation as the main task with action guide as the method and evaluation system as the standard. This base comprehensively constructs a real simulation training platform and forms a real training platform that is open and professional. For another hand, HUCVTC highly emphasizes the organization and management on practice teaching, perfects practice teaching organizations and sets up practice teaching system, such as standard file system, examining system and evaluation system, so as to ensure the smooth implementation of practice teaching and the completion of teaching tasks.

In the past years, HUCVTC, depending on the spring wind of higher vocational education reform and development, made correct and scientific decisions and grasped opportunities. With innovative thoughts and strong faith and through integrating resources, operating house properties and lands of HUCVTC, and enhancing connotation construction, radical changes occurred in HUCVTC in just two or three years. HUCVTC made new exploration and practice in education ideology, education concepts, education investment system, college teaching system and education management system. HUCVTC also formed features in the innovation in talent cultivation modes, real simulation training bases, college and enterprise cooperation and social services, which lays solid foundation for sustainable development and reform of HUCVTC. 


\section{References}

Tutorship Book for the Report to the Seventeenth National Congress of the Communist Party of China. Beijing: People's Press, 2007.

Li, Zhi \& Wang, Youhua. (2007). A probe into college culture construction system. Higher Education Research and Reform, the $3^{\text {rd }}$ issue.

Li, Zhi \& Wang, Youhua. (2007). Spirit is also the productivity for developing colleges. China Construction Education, the $3^{\text {rd }}$ issue. 